DOI: $10.17516 / 1997-1370-0885$

УДК 76.03./09:769:82

\title{
West-European Engraving in Siberian Collection: the Problems of Attribution (on the Basis of Yudin's Collection)
}

\author{
Svetlana A. Iakovleva and Iuliia A. Kolpakova* \\ Dmitri Hvorostovsky Siberian State Academy of Arts \\ Krasnoyarsk, Russian Federation
}

Received 10.10.2021, received in revised form 10.12.2021, accepted 18.01.2022

\begin{abstract}
The paper is devoted to the study of Siberian bibliophile G. V. Yudin's WestEuropean graphic arts collection, which is owned by the Krasnoyarsk Regional Local Lore Museum. There is an objective need to give additional information on the attribution of auteur, reproductive and book engravings in art and documentary research. The authors address the authorship attribution through art analysis using stylistic and biographical factors. The article also responds to the problem of relevant translation of proper nouns (artists, engravers, printers, publishers) and texts on graphics. The study presents the results of literary translation of engraving texts (legends, book illustrations, caricatures). The translation is based on the knowledge of characters' language, intentions of the author and reflects the unity of visual artwork and the literary source.
\end{abstract}

Keywords: artist, engraver, engraving, engraving techniques, reproduction, G. V. Yudin, Siberian collection.

Research area: art history.

Citation: Iakovleva, S.A., Kolpakova, Iu.A. (2022). West-European engraving in Siberian collection: the problems of attribution (on the basis of Yudin's collection). J. Sib. Fed. Univ. Humanit. soc. sci., 15(1), 23-37. DOI: 10.17516/1997-1370-0885

(C) Siberian Federal University. All rights reserved

* Corresponding author E-mail address: masdisf555@mail.ru, gellarousse@mail.ru

ORCID: 0000-0003-3630-8499 (Iakovleva); 0000-0001-5523-4291 (Kolpakova) 


\title{
Западноевропейская гравюра в сибирской коллекции: проблемы атрибуции (по материалам собрания Юдина)
}

\author{
С.А. Яковлева, Ю.А. Колпакова \\ Сибирский государственный институт искусств им. Д. Хворостовского \\ Российская Федерачия, Красноярск
}

\begin{abstract}
Аннотация. Статья посвящена исследованию части собрания сибирского коллекционера, библиофила Г.В. Юдина. Поставлена цель изучить западноевропейское собрание графики Г. В. Юдина, хранящейся в фондах Красноярского краевого краеведческого музея. Существует объективная потребность в ходе искусствоведческого и документального исследований внести ряд уточнений в атрибуцию авторских, репродукционных и книжных гравюр. Решается задача установления авторства путем искусствоведческого анализа с помощью стилистического и биографического факторов. Рассматривается проблема корректного перевода имен собственных (художников, граверов, печатников, издателей), подписей под графическими произведениями. Представлены результаты художественного перевода текста гравюры (текста-легенды, книжной иллюстрации, карикатуры), опирающегося на знание языка героев, замысла автора, умение отразить единство композиции изобразительного поля с литературным источником.
\end{abstract}

Ключевые слова: художник, гравер, гравюра, техники гравирования, репродуцирование, Г. В. Юдин, сибирская коллекция.

Научная специальность: 17.00.04 - изобразительное и декоративно-прикладное искусство и архитектура.

\section{Введение}

Одной из актуальных задач при описании музейных собраний графики является атрибуция - определение авторской принадлежности, места, времени создания. Оттиск гравюры несет в себе информацию о художнике, гравере, издателе, печатнике, технологиях гравирования. Определенные трудности возникают в силу отсутствия подписи автора, наличия подделок в установлении автора оригинала, плохой сохранности гравюры, проблем музейной атрибуции.

Соотношение визуального и текстового полей печатной страницы закладывалось одной из первых графических техник - ксилографической гравюрой. В нидерландской ксилографии XV в. упрощенный рисунок декорировали лентой с краткими библейскими надписями («Апокалипсис», ок. 1420-1430-х гг.). Религиозная тема становилась ведущей в ксилографии в виде станковых гравюр и иллюминированных книг. Бытование текста вошло в практику с первых манускриптов, печатных инкунабул, фолиантов и служило важнейшим элементом страницы, неся в себе пояснительносопровождающую, вербальную функцию.

\section{I. Методология}

Методологическая основа исследования сформулирована на базе теорий, изложенных такими классиками искусствознания, как Г. Вельфлин, Э. Панофский, Б. Р. Виппер, А.Г. Габричевский и др. В основу изучения заявленной проблемы положен комплексный подход, который включает искусствоведческое, источниковедческое исследования, позволяющие проанализировать стилистические признаки, 
иконографию, культурно-биографические, документальные, архивные и музейные материалы.

\section{II. Результаты}

\section{1. Морфология графического листа}

Традиция текста (подписи, тексталегенды, поясняющего текста) укоренилась в искусстве графики в религиозном, мифологическом, историческом, бытовом жанpax, пейзаже, книжной гравюре, карикатуpe. Структура морфологии листа гравюры включала в себя основные подписи художника, гравера, печатника, издателя, а также сопутствующие подписи - состояние, переиздание, ремарки на полях. В портретном жанре на лицевой стороне листа (в тексте под гравюрой по центру) указывались имя портретируемого, статус, должность, титул. В других жанрах использовали тексты исторические, мифологические, дидактические, а также цитаты из художественной литературы.

Сложилась определенная практика оформления лицевой части гравюры: в нижней части изобразительного поля, слева и справа - в зависимости от формы листа (квадрат, прямоугольник, овал) уменьшенным шрифтом гравировали имена художника и гравера, печатника и издателя. Художник мог выступать автором живописного оригинала, рисунка, гравюры, гравером (резчиком гравюры), печатником и издателем. Мастер-гравер резал на дереве, меди и т. д., используя живописный оригинал художника или его авторскую гравюру, далее выполнял оттиски. Подписи имен и сведения о форме участия художника, гравера, печатника, издателя при создании гравюр указывались на латыни или на языке авторов, гравировались мелким шрифтом сокращенно. Рядом с именем автора могли быть обозначения на латыни или на языке оригинала полностью или сокращенно. Например, inventor (англ. изобретатель, автор изобретения; тот, кто изобрел, придумал; сокр. invt, inv, in); delineavit (лат. нарисовал; сокр. delin, del, delt); pinxit (лат. написал, нарисовал; сокр. pinxt, pinx, pin, pt). Что касает- ся имени гравера, могли быть следующие обозначения: sculpsit (лат. вырезал, гравировал; сокр. sculpt, sculp, sc); graved (англ. гравировал; высекал; вырезал); engraved (англ. гравировал, резал (по камню, дереву, металлу); сокр. grave, grav, gr); gravé (франц. выгравировано, вырезано, высечено); fecit (лат. сделал; сокр. fec, fe, f). Для указания имени издателя использовалось слово «excudit» (лат. изготовил, оттиснул, выполнил, напечатал; сокр. excud, exc, ex). Данные печатника обозначались следующими способами: impressit (лат. изготовил, выполнил, оттиснул; сокр. imp, impe); imprimeur (франц. печатник, типограф; сокр. imp, impr); imprimé (франц. напечатано). Также можно встретить на листах монограммы автора и привилегии на издание.

Наиболее внимательного изучения требует визуально-вербальный нарратив как основной источник толкования содержания станкового и книжного графического листа, его подписей и текстовых источников. Социально-эстетические причины повлияли на свойства графики - тиражность, массовость, доступность. Учитывая социальный аспект гравюры, она выполняла дидактическую, познавательную, агитационную роль, формировала общественное мнение. Последнее касалось в том числе графической карикатуры, в композиции листа которой объединялся реальный или фантастический рисунок с острыми, едкими политическими текстами.

\section{2. Принцип коллекционирования}

\section{Г. В. Юдиным зарубежной графики}

Сибирские коллекции В.Н. Баснина (1799-1876), Н.В. Баснина (1843-1918), собрания графов Строгановых, князей Голицыных в Томском университете, И.И. Казаринова (1833-1902), М.В. Сурина (1834-1903), .В. Юдина (1840-1912), В.П. Сукачева (1849-1920), Н.Ф. Катанова (1862-1922) и других включали собрания XVI-XX вв. универсальной тематики, иллюстрированные книги, гравюры. Профессиональный системный подход коллекционирования западноевропейской графики присущ собранию сибирских купцов Бас- 
ниных, переданному впоследствии в Румянцевский музей (1918).

Полное собрание трудов правоведа и искусствоведа А.Д. Ровинского в коллекции библиофила Г.В. Юдина свидетельствует о его знакомстве с историей формирования зарубежного и отечественного графического наследия. Юдинское собрание альбомов, серий и графических листов рассказывает о жанровых предпочтениях коллекционера - от религиозных мотивов до карикатуры. После продажи книжной коллекции Г.В. Юдина Вашингтонской Национальной библиотеке (Библиотеке Конгресса США) (Ф. 796. Оп. 1. Д. 4791а. Л. 60-61) в 1906 г. и национализации второй библиотеки в 1920 г. коллекция графики в такой же мере была разрознена и утратила свою целостность (Ф. 796. Оп. 1. Ед. хр. 4716. С. 19; Polovnikova, 2010: 268; Polovnikova, 2008).

Лингвистический подход является важной частью смысловой интерпретации переведенного текстового материала графического листа. Он необходим для сохранения эквивалента перевода и смыслового содержания текста. Следует учесть особенности перевода основных и сопутствующих данных листа - фамилий граверов, художников, издателей; адресов, топонимов для уточнения атрибуции гравюры в коллекции. При переводе текста гравюры должны учитываться особенности языка оригинала, культуры, понимание фундаментальных культурных основ для погружения, согласно семиотическому учению Ю. Лотмана, «в контекст культуры».

Приобретая зарубежную художественную литературу и графику, Г.В. Юдин отдавал предпочтение французским, английским, немецким произведениям (Mitasova, Kostyuk, Romanova, Shutova, Yakovleva, 2019: 405). Предполагаемая осведомленность собирателя Юдина о графической коллекции Басниных и изучение собрания А.Д. Ровинского послужили ему поводом для приобретения одних из лучших гравюр европейских коллекций XVIII в., в частности собрания репродукций гравюр У. Хогарта (1697-1764), широко известного европейским знатокам, граверам, издателям. Кроме того, Юдин приобрел книжные иллюстрации признанного мастера Даниеля Николауса Ходовецкого (1726-1801), создававшего гравюры по собственным рисункам, а также по сочинениям Вольтера, Гете, Ариосто, Стерна, Руссо, Шиллера, Лессинга, Жан-Мишеля Моро Младшего (1741-1814), вошедшего в историю графики серией «Памятник костюму».

Обозначение авторства на литографических листах выглядело иначе. Авторские подписи и имя издателя сокращались, имели несколько вариативных форм. Напримep, lith. de (франц. литографировал); imp. lith. de (франц. напечатал, литографировал); delineavit (лат. нарисовал; сокр. delin, del, delt); dessiné sur pierre par (франц. рисовал на камне).

\section{3. Проблемы атрибуции произведений графики английской, французской школ}

Английская культура в сибирской коллекции представляла собой, прежде всего, подборку художественной литературы, публицистики, трудов в области науки, техники и государственно-правовых вопросов (Iakovleva, 2019: 12) XVIII - начала XIX в. Подборка графического наследия собрания визуально отражала эпоху английского Просвещения с новыми формами гражданского поведения и принципами нравственности.

«Современные нравственные сюжеты» («История распутника», «История распутницы», «Модный брак» и др.) художник, гравер У. Хогарт издавал без сопроводительных текстов. Сопровождение выпускаемых копий его гравюр комментариями о главных героях, пояснениями сюжетной линии, стихами впоследствии создало традицию и норму при публикации гравюр. В альбоме копий графики Хогарта, выполненных немецкими граверами XIX в. Э.Л. Блау, К.Ф. Хейнтцем, К.К. Беме, В. Эрентраутом в 1833-1834 гг., находим свидетельство интереса к творчеству Хогарта времен формирования немецкого национального движения. Воспроизведены гравюры с пояснительным текстом в лито- 
графической технике. Например, «Ночь»: «Достаточно светло, поскольку костры, фейерверки, факелы, хорошо освещенные дома, фонари и т. д. прогоняют тьму. Особенно светло у цирюльника, где, согласно вывеске, хорошо стригут бороды, пускают кровь, одним рывком удаляют больной зуб. $<\ldots>$ Каменщик так много выпил, <..> должен вести его домой. Кажется, что каменщик что-то знает об опасности» (рис. 1). Часть гравюр не снабжена именами автора картины, гравюры (отсутствует необходимая надпись «W. Hogarth inv. pinx») и граверов, переносивших изображение на печатную форму.

Немецкий гравер Э. Л. Рипенгаузен неоднократно обращался к изданию копий с гравюр Хогарта. В типографии Геттингенского университета Э.Л. Рипенгаузен практиковался в иллюстрировании научных исследований, занимался выпуском альманахов, календарей с миниатюрными гравюрами, в том числе репродукциями с работ Хогарта. Репродуцируя с гравюр Хогарта, Э.Л. Рипенгаузен обязательно указывал слева «W. Hogarth inv. pinx. [У. Хогарт придумал, писал красками]», справа «E. Riepenhausen del \& fe [Э. Рипенгаузен рисовал и гравировал]» (рис. 2).

Сложность атрибуции состоит в том, что гравер выполняет репродукцию с картины или с авторской гравюры художника, создает рисунок, вырезает его на медной доске и печатает, но порою не указывает

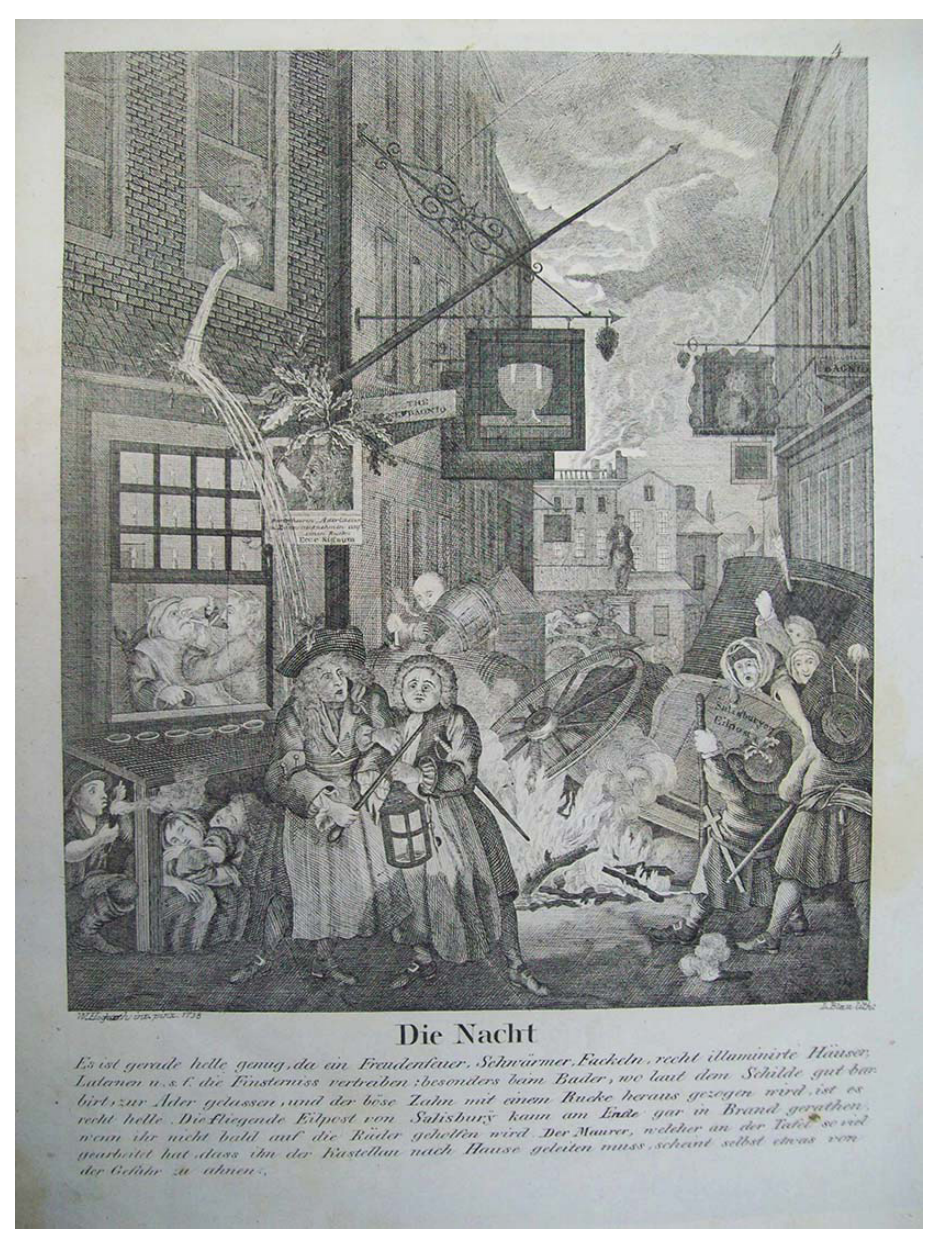

Рис. 1. Гравер Л. Блау. Ночь. Автор оригинала У. Хогарт. 1833-1834

Fig. 1. The engraver: L. Blau. Die Nacht. The inventor: William Hogarth. 1833-1834 


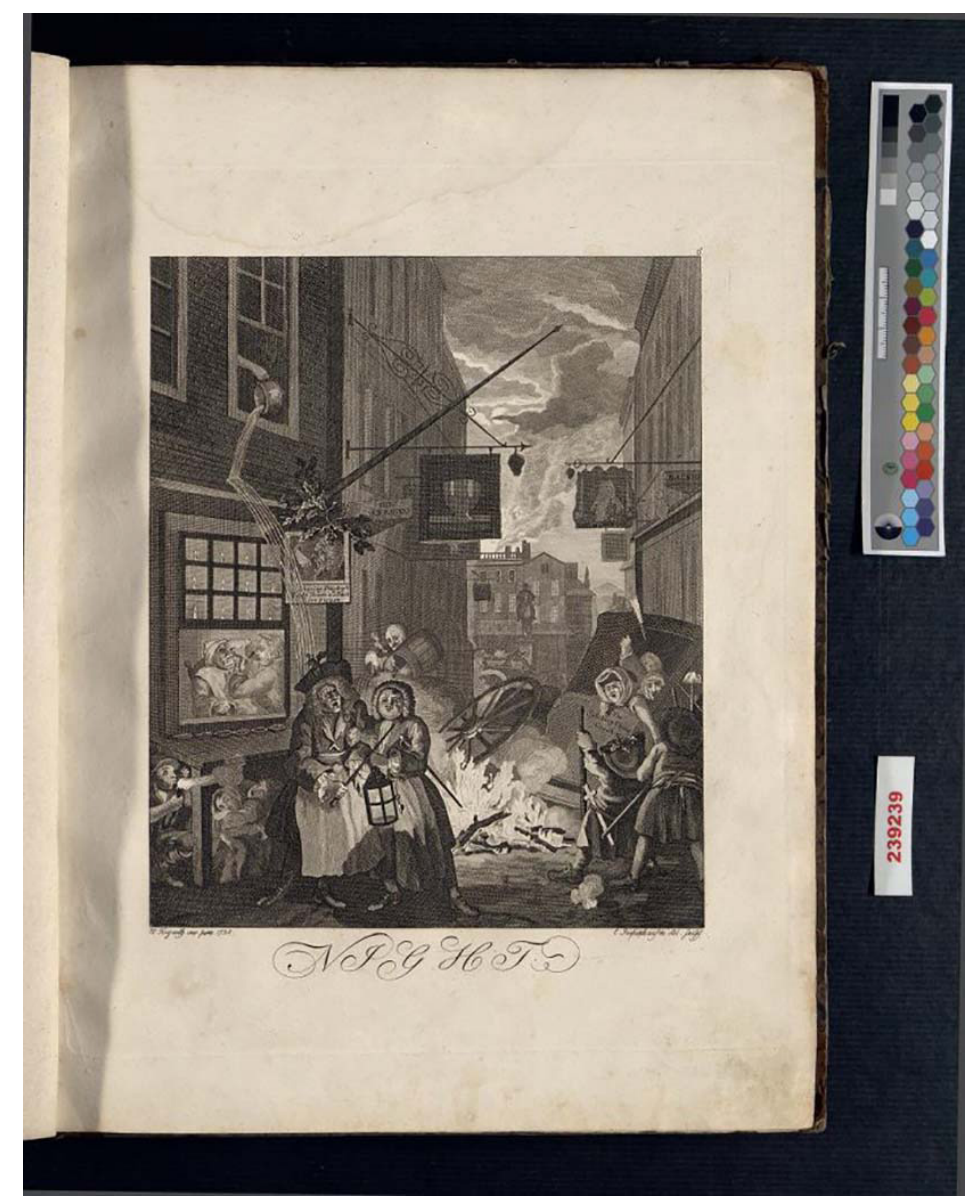

Рис. 2. Гравер Э.Л. Рипенгаузен. Ночь. Автор оригинала У. Хогарт. 1738

Fig. 2. The engraver: E. L. Riepenhausen. Night. The inventor: William Hogarth. 1738

авторство художника и гравера в одном лице. В полной атрибуции указывается автор копии - Рипенгаузен, автор оригинала и гравюры в одном лице - Уильям Хогарт. Выполняя лист четвертый «Ночь» из серии «Четыре времени суток» по собственной композиции, художник перечислил автора идеи, картины, гравюры и издателя - «Invented Painted Engraved \& Published by Wm Hogarth March 25. 1738 [Придумал, написал, выгравировал и опубликовал У. Хогарт 25 марта 1738]». В альбоме юдинской коллекции листы репродукций Хогарта выполнены в технике литографии, повторяя манеру резцовой гравюры и офорта графических оригиналов. Отличается лист № 60 Э. Л. Блау с репродукци- ей портрета У. Хогарта «Девушка с креветками» (1763). Художник передал радость бытия легкой, импрессионистической тональностью, в «свободной, ничего не боящейся импровизации» (German, 1977: 201), что разнилось с обычно присущей ему живописной и нравоучительной манерой. Одна из последних работ художника репродуцировалась Ф. Бартолоцци (рис. 3), который, следуя за оригиналом, пунктиром и сангиной воспроизводил палевоохристые тональности портрета. Под портретом слева выгравировано «W. Hogarth pinx. [У. Хогарт написал маслом]», справа - «F. Bartolozzi sculp [гравировал Ф. Бартолоцци]». В надписи «Publish'd March 25 th 1782 by Jane Hogarth [Опубли- 


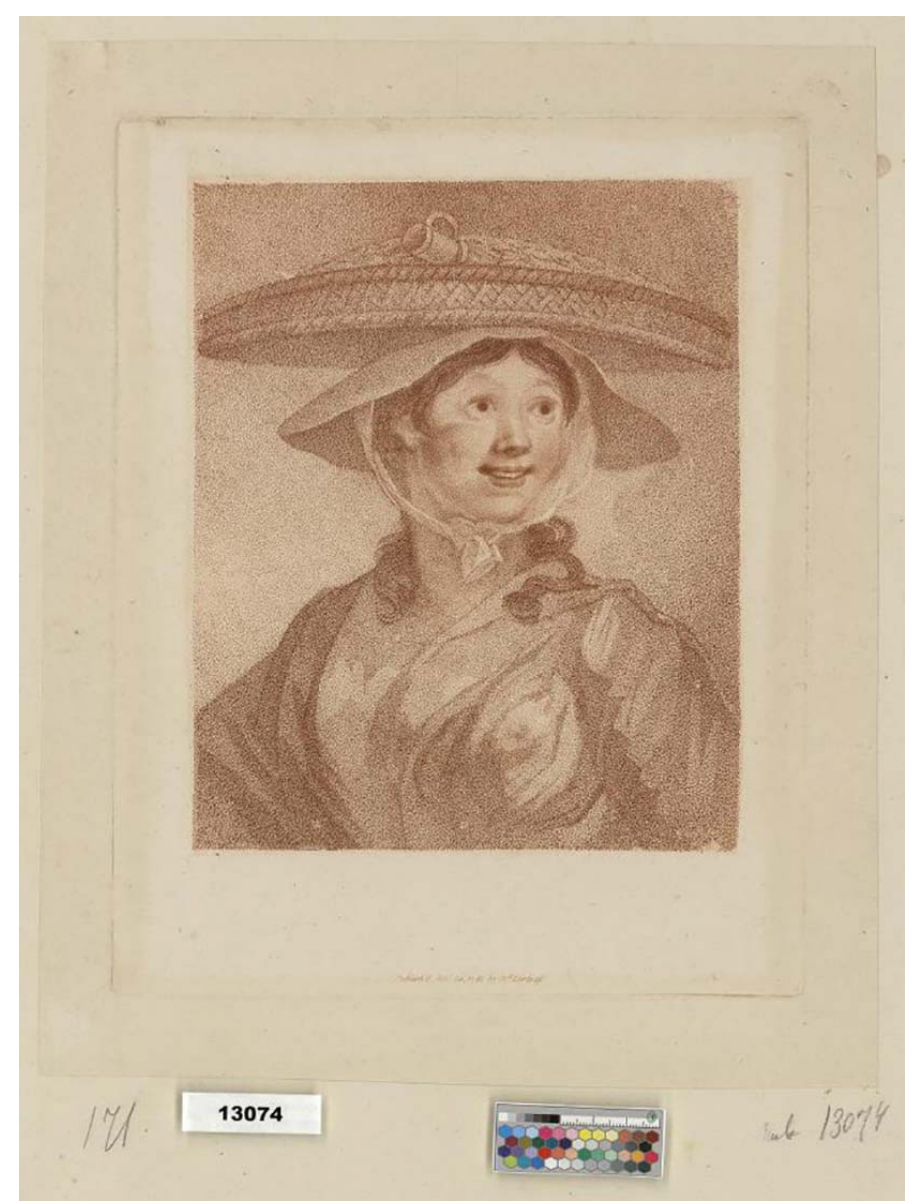

Рис. 3. Гравер Ф. Бартолоцци. Продавщица креветок. Автор оригинала У. Хогарт. 1782

Fig. 3. The engraver: F. Bartolozzi. Shrimps. The inventor: William Hogarth. 1782

ковано 25 марта 1782 года Джейн Хогарт]» сообщалось о публикации по оригиналу Хогарта вдовой художника Джейн Хогарт в 1782 г. Блау репродуцировал в литографической технике, передавая воздушную, мягкую пунктирную манеру.

Репродуцированием с картин и гравюр Хогарта занимались его родные, сотрудничая с профессиональными граверами и издателями. После смерти Хогарта вдова художника передала доски издательству Бойделлей с договором о ренте. Успех произведений Хогарта подтверждался выпуском альбома Джоном (1719-1804) и Джозайей (1752-1817) Бойделлями, Р. Ливси (1750-1826), С. Айрлендом (1744-1800), Ф. Бартолоцци （1727-1815)， Э. Л. Рипен- гаузеном; выпуском отдельных гравюр У. Блейком (1757-1827) и др.

Глядя на гравюру Э.Л. Блау (рис. 4), можно предположить, что она выполнена с гравюры Бартолоцци. Обращенный зеркально лист в точности передавал детали одежды, светотень, блюдо с креветками, кувшин. Пояснительный текст на немецком языке ${ }^{1}$ знакомил зрителя с изображае-

\footnotetext{
1 В этом произведении наш Хогарт выступает в роли неизвестного сатирика, а художника, изображающего первозданную природу. На полотне мы видим молодую английскую деревенскую девушку, которая приходит в город с креветками, чтобы <..> продать их. При этом она кричит: «Креветки, креветки». Хогарт представляет портрет девушки, привлекшей его внимание и не обладающей при этом совершенной красотой. Однако, по крайней мере, мы точно можем назвать ее милой
} 


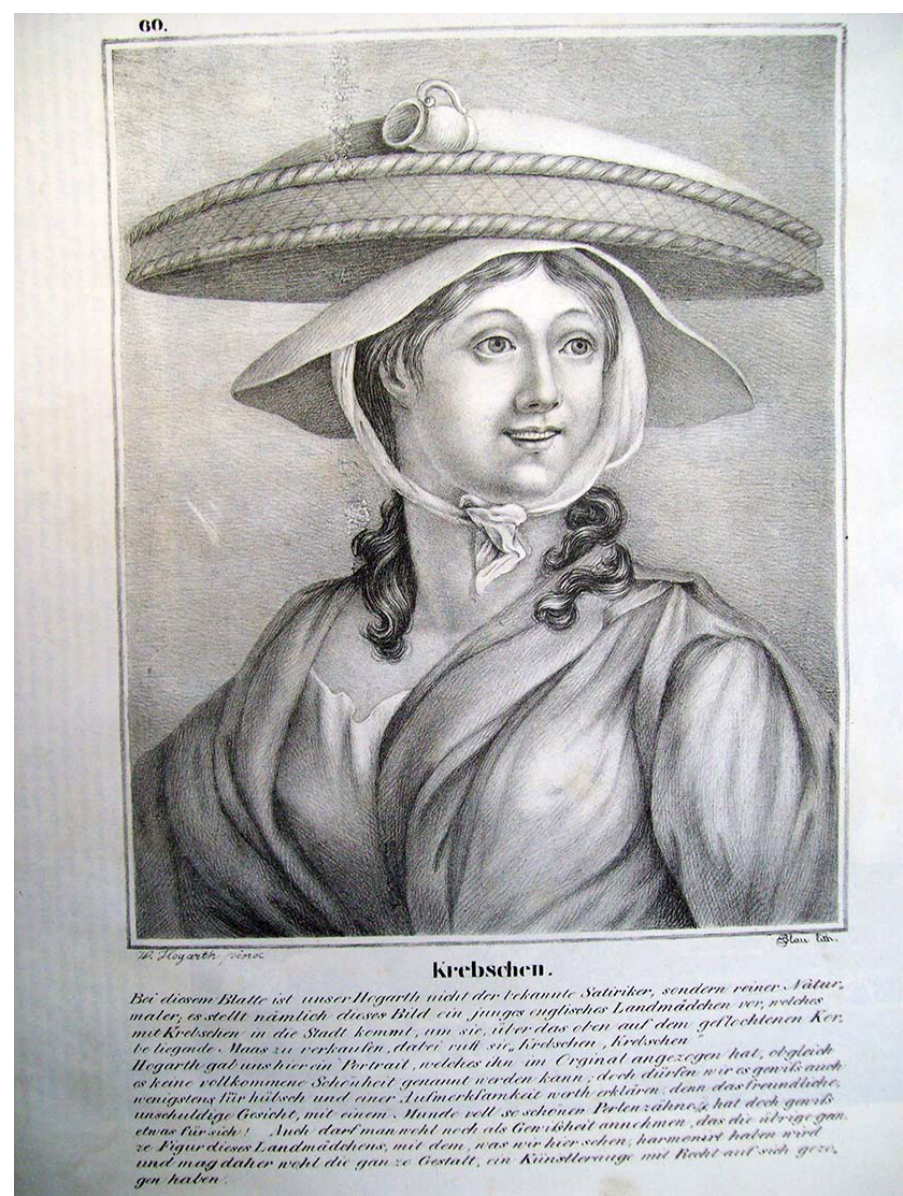

Рис. 4. Гравер Л. Блау. Продавщица креветок. Автор оригинала У. Хогарт. 1833-1834

Fig. 4. The engraver: L. Blau. Krebschen. The inventor: William Hogarth. 1833-1834

мой на портрете девушкой. Слева и справа выгравированы имена художника и гравеpa: «W. Hogarth pinx [написал У. Хогарт]», «Blau lith. [литография Блау]».

Издательство Р. Аккермана (1764-1834) занималось выпуском гравюр, журналов, альманахов. Три листа коллекции, опубликованные в издательстве, выполнены в технике резцовой гравюры, офорта Э. Ф. Финденом (1791-1857), Г. Ч. Шентоном (1803-1866), Р.У. Уоллисом с работ королевского академика Г. Томсона, художни-

и достойной внимания, т. к. в этом приятном и невинном лице, в красивых зубах-жемчужинах что-то есть. Также можно с уверенностью предположить, что вся фигура этой деревенской девушки гармонирует со всем, что мы здесь видим, и поэтому она по праву заинтересовала художника. ков Дж. Оуэна и Г. Дж. Рихтера. Трудность атрибуции касается листов, в которых данные исполнителей гравируются не полностью. Сюжет гравюры под названием «Тhe Kent, East Indiaman ${ }^{2}$ [Кент, Ост-Индская компания]» (рис. 5) связан с трагическим событием - пожаром на корабле в 1825 г., что побудило многих художников написать свои версии гибели судна. В семье потомственных граверов Уоллисов, среди которых наиболее известен Р.У. Уоллис (1794-1878), репродукциями занимались совместно с Ч. Хитом: воспроизводили полотна Тернера, иллюстрировали альбомы,

2 Pub. by R. Ackermann. London. 1828 [Опубл. Р. Аккерманом. Лондон. 1828; J. Owen. del. ${ }^{t}$ [нарисовал Дж. Оуэн]; Wallis sculp.t [гравировал Уоллис]. 


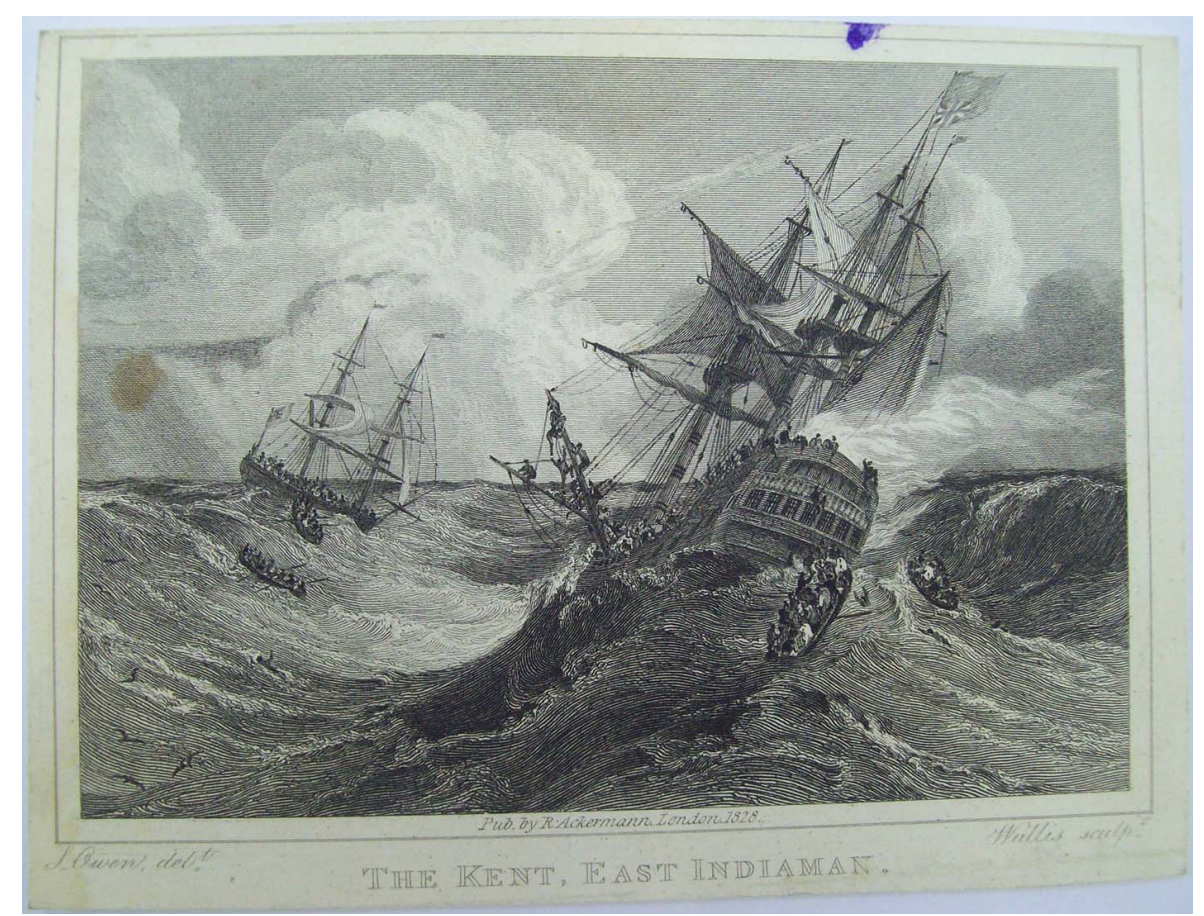

Рис. 5. Гравер Р. Уоллис. Кент, Ост-Индская компания. Автор оригинала Дж. Оуэн. 1828

Fig. 5. The engraver: R. Wallis. The Kent, East Indiaman. The inventor: J. Owen. 1828

журналы, а также произведения В. Скотта, С. Роджерса, Т. Кэмбелла. При издании гравюры подпись дана не полным именем, а сокращена до «Wallis sculp. '[гравировал Уоллис]», в то время как полное имя гравеpa - Роберт Уильям Уоллис (Robert William Wallis). История создания гравюры «The booroom slave [Невольница]» Е. Финденом (E. Finden sculp.), опубликованной Р. Аккерманом (Pub. by R. Ackermann. London. 1828) по картине Г. Томсона (H. Thomson del.t), является откликом на движение аболиционизма в Великобритании, отмену рабства, окончательно провозглашенную в 1838 г.

Среди европейской коллекции Юдина собрание французской литературы и графики занимало ведущее положение. Широко представлена в коллекции графика французских граверов и издателей XVIIIXIX вв. Гюбера Франсуа Гравело (16991773), Жан-Батиста Ле Ба (1729-после 1795), Жан-Мишеля Моро Младшего (1741-1814), Шарля Этьена Пьера Мотте (1784-1836), Н. Л. Делонуа, Жана Иньяса Изидора Гран- виля (1803-1847), Луи Лассаля (род. 1810) [14] и др.

Классическая манера книжных французских граверов XVIII в. основывалась на репродукционной передаче портретов и картин жанровой тематики, переданных резцом и офортом. Наиболее сильна французская графика XVIII в. в книжной иллюстрации и издании серий и офортов с картин, рисунков А. Ватто, Ж.-Б. Греза, Ж.-О. Фрагонара и др. В огромном наследии одного из лучших иллюстраторов Франции Ж. М. Моро Младшего - книжная гравюра, рисунки к изданиям, сборникам, сюитам (Vodo, 1987: 222). С изменением в области искусства, интересом к рисунку во Франции второй половины XVIII в. начала XIX в. классицистические техники ксилографии, резца, офорта дополняются карандашной и пунктирной манерой, акватинтой, лависом, литографией.

В Красноярском краеведческом музее хранится графическая коллекция Юдина с лучшими десятью листами по рисункам 
Ж. М. Моро Младшего к произведениям Мольера, Вольтера, Ж.-Ж. Руссо. Например, «Альзира, или Американцы» (1736), «Царевна Вавилонская» (1768), «Задиг, или Судьба» (1747), «Жюли, или Новая Элоиза», «Тартюф, или Обманщик» (1664). Работы выполнены граверами А.-Л. Романэ (1748-1807), Э. де Гендтом (1738-1815), А. К.Ф. Виллереем (1754-1828), Ж.-Л. Делиньоном (1755-1804).

Один из выдающихся художников и граверов XVIII в. Ж.М. Моро Младший создавал рисунки, гравировал по собственным работам и произведениям других живописцев. Многие листы коллекции, иллюстрирующие литературные произведения по рисункам Моро, отражали эпоху, нравы, костюм. При переводе отрывка из литературного произведения, сопровождающего иллюстрацию, необходимо принимать во внимание связь со стилем и культурой этого периода, с визуальным материалом, а также учитывать устойчивые выражения прошлых времен. Морфология листов выполнена по устоявшейся традиции оформления: «J.-M. Moreau le J e inv. Гавтор идеи Ж.-М. Моро Младший]», «Е. de Ghendt Sculp [гравировал Э. де Гендт]», «J. Moreau inv. del. [автор идеи, рисовал Ж. Моро]», «Delignon Sculp [гравировал Делиньон]». Возможно, в первом случае упущено, что Моро являлся не только автором идеи, но и автором рисунка (del).

Для сохранения содержания изображенного важен точный перевод текста оригинала на другой язык, особенно литературного текста под иллюстрацией. Искусствоведческий анализ графических произведений европейских школ требует непротиворечивого перевода для правильности атрибуции и интерпретации сюжетной линии. В подписи к иллюстрации философской повести «Задиг, или Судьба» указаны автор рисунка Ж.-М. Моро Младший и гравер Э. де Гендт. Полное имя гравеpa - Emmanuel Jean Népomucène de Ghendt»

\footnotetext{
3 «O puissances immortelles!... me rendez-vous Astarté?...» / Zadig / J.-M. Moreau le Je inv. / E. de Ghendt Sculpt. [O, бессмертные силы!... вы возвращаете мне Астарту?... / Задиг / Ж.-М. Моро Младший].
}

(Эммануэль Жан Непомюссен де Гент), и при указании авторов некорректно сокращение в музейном тексте до «Ghendt, E. de», так как после предлога родительного падежа dе должно стоять существительное, а не наоборот.

Иллюстрация к роману Руссо «Жюли, или Новая Элоиза» (часть I, письмо XXXI) выполнена по рисунку (J. Moreau inv. del.) гравером (Delignon Sculp) и сопровождается следующим музейным текстом: Que devins-je, en entr'ouvrant la porte, qu'and j'apperçus celle qui devroit être sur la $^{4}$ trône de l'univers à terre, inondé de ses larmes? В оригинальном произведении Руссо текст выглядит так: Que devins-je, en entr'ouvrant la porte, qu'and j'aperçus celle qui devroit être sur le trône de l'univers, assise à terre, la tête appuyée sur un fauteuil inondé de ses larmes? [Что сталось со мною, когда, полуотворив дверь, я увидел, что та, которой должно восседать на престоле Вселенной, сидит на полу и, припав лицом к креслу, обливает его потоками слез] (пер. А. Худадовой) (Rousseau, 1761). В надписи под иллюстрацией Моро отсутствуют некоторые слова, например опущен оборот «la tête appuyée sur un fauteuil [припав лицом к креслу]». Возможно, автор посчитал, что слово «кресло» (франц. fauteuil), которое довольно прозаично и уже присутствует на гравюре, могло бы исчезнуть и быть заменено на некоего мужчину, которого в приоткрытой двери «та $<\ldots>$ обливает потоками слез» на расстоянии. Такая интерпретация возможна благодаря тому, что во французском языке слово fauteuil [кресло] мужского рода и причастие inondé [обливаемый, заливаемый, затопленный] также употреблено в мужском роде, а следовательно, теоретически может относиться как к креслу, так и к мужчине. Таким образом, подобно режиссеру (metteur en scène франц. режиссер, постановщик, досл. перекладывающий на сцену) художник - это своего рода metteur en image, то есть «перекладывающий» литературное

\footnotetext{
4 В тексте написано la trône, что, безусловно, является ошибкой, поскольку слово trône во французском языке мужского рода - le trône. То же касается глагола apercevoir (j'aperçus), который пишется с одной буквой р.
} 
произведение на язык картины. Его цель затронуть читателя «сконцентрированным» текстом, при этом учесть и передать его основной смысл.

Литографическая техника завоевывала свои позиции в европейской графике XIX в. Во Франции ее совершенствованием занимались Г. Энгельман, Ж.-Р. Лемерсье, Ж. Сент-Эвр, акварельную подкраску использовали Ж.И. Гранвиль, Л. Лассаль, Н.-Л. де Делонуа, Ш. Э.П. Мотте. Французские литографии представляют собой ряд сентиментальных и сатирических сцен, истолкованных в свете теорий романтического остроумия.

Детская тема становится основной в живописи Л. Лассаля. В своих карти- нах он отражал реальность окружающего мира, место детства в череде революций, давая этому критическую оценку в художественном воплощении. Он автор рисунков литографированных сюит (например, «Bals Masqués de Paris [Балы-маскарады Парижа], в русском переводе - «Листы из сюиты костюмов») и серий. Одна из серий - «Детские забавы» - хранится в фонде музея, выполнена в Париже в середине XIX в. Надпись в правом углу изобразительного поля листа «Юные садовники» («Le petit jardin [Маленький сад]», рис. 6) гласит: «Louis Lassalle»; под гравюрой слева и справа - «L. Lassalle del et lith [рисовал и литографировал Лассаль]», «Imprimé par A. Godard [напечатано

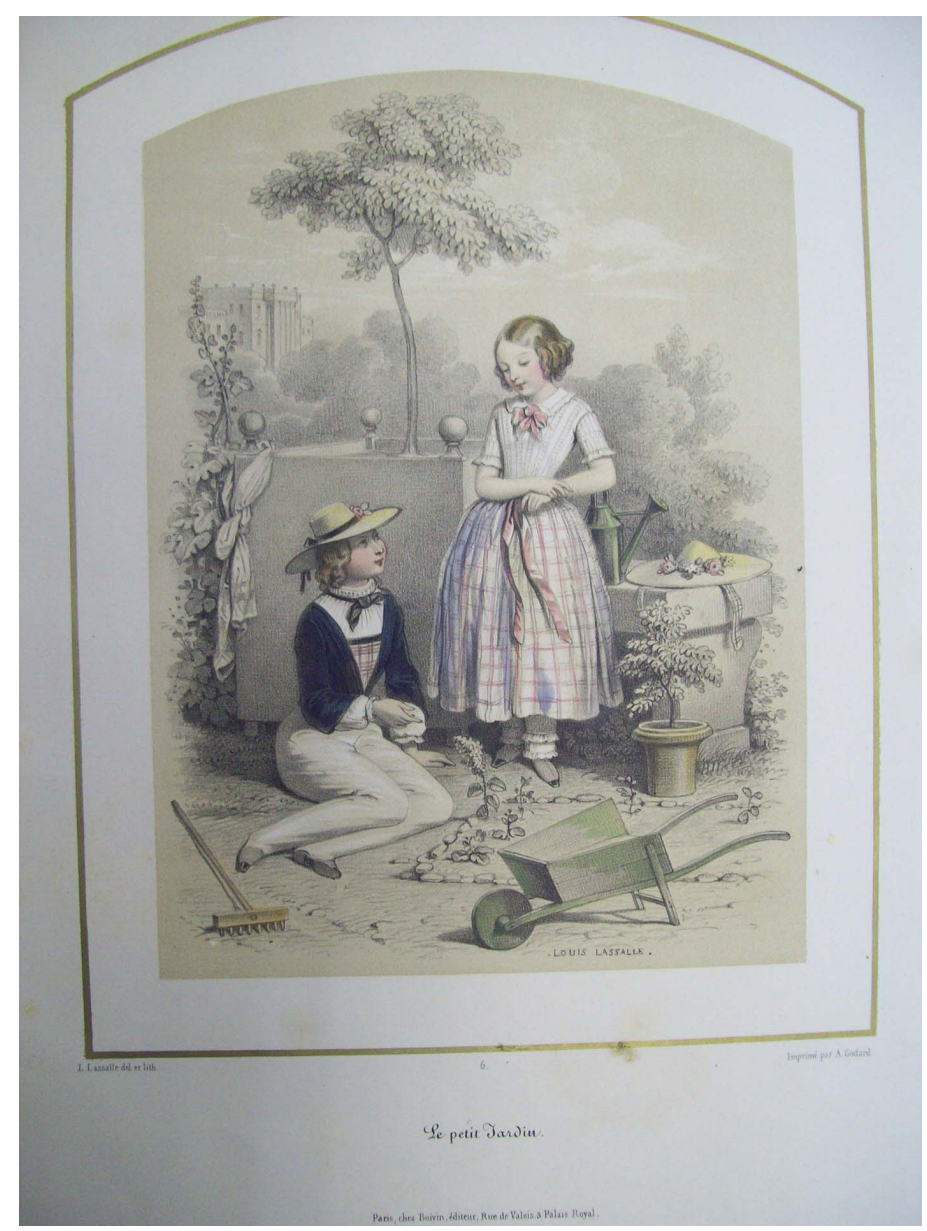

Рис. 6. Гравер А. Годар. Юные садовники. Автор оригинала Л. С. Лассаль. Середина XIX в. Fig. 6. The engraver: A. Godard. Le petit Jardin. The inventor: L. Lassalle. The mid-nineteenth century 
А. Годаром]». Подлинность и авторство подчеркивается подписью художника, выполненной прописными и строчными буквами.

Творчество Ж. И. Гранвиля строилось на знании театра и театральных подмостков, графики Калло, английской карикатуры и сатирической прессы. Необычность его персонажей в передаваемом образе отражалась в гибридном объединении черт человека и животного. Пройдя обучение у художника-миниатюриста Андре Леона Ларю (1785-1834), Гранвиль работает в Париже. Он занимается выпуском литографических серий, одна из них - «Метаморфозы дня» (1829) - исследует нравы общества. В дальнейшем он публикует политическую сатиру в периодических изданиях «Карикатура», «Шаривари» (Grandville, 2010; Struina, Besedina, Lobacheva, 2017: 12). Лист «Сатира на дуэль» пародировал сложившуюся моду на поединки во всех сфеpax общества - политиков, военных, дворян, интеллигенции. Дуэль становилась фальсификацией возмездия, сатисфакции поруганной чести. Литография тонирована акварелью, в подписях «J. J. Grandvill» и «F. J. Grandvill»5 в карточке необходимы уточнения. Кроме того, при описании содержания вкралась неточность в трактовки персонажей: изображены мужские фигуры с головами лангуста, дикобраза, гуся и лис, в то время как в описании указаны еж, рак, гусь и двое с лисьими головами. Лист из «Метаморфоз дня» дается под названием диалога персонажей "Que diable, monsieur, on ne recule pas comme ça [Какого черта, месье! Мы так не отступаем]»; «Oh! je suis brave à ma manière... J'avance en reculant» [O, я храбрый по-своему... я продвигаюсь, пятясь]». Литография выполнена рисовальщиком, издателем, литографом

\footnotetext{
5 Имя рисовальщика - Жан Иньяс Изидор Гранвиль (франц. Jean Ignace Isidore Grandville). Помимо опечатки в фамилии, инициалы должны быть J. I.I. Grandville. Одна из опечаток в инициалах, вероятно, возникла в связи со схожестью в графическом написании заглавных букв J и I.
}

Пьером Ланглюме (1790-1830) («Langlumé, Pierre, dessinateur-lithographe»), иллюстрирующим труды Л. Чориса, Ж. Кювье, Э. Ж. Сент-Илера, репродуцирующим произведения Фрагонара, Прудона и др.

Профессионально литографией занимался Ш. Э.П. Мотте. Получив патент, он обратился к портрету и книжной, научной иллюстрации. Благодаря сотрудничеству в ежедневной газете «Le Miroir des spectacles, des lettres, des moeurs et des arts [Зеркало спектаклей, литературы, нравов и искусств]», независимо от главной ее темы он создавал сатирические политические и нравственные композиции. Эзоповым языком лист «Квартет дураков» передает отношение к политикам времен Реставрации. Литография выполнена Мотте (Lithog. ie de C. Motte). Можно предположить, что он являлся и автором, и издателем данной работы.

В композицию подкрашенной акварелью литографии Делонуа «Не бойтесь, ваш муж читает «Котидьен» (периодическое издание) добавлена объемная деталь (рис. 7). На стену изображенного дома приклеен ставень окна, он приоткрыт, виден мужской силуэт - тем самым вносится интрига в сюжет. Можно предположить, что согласно подписи под литографией «Lith. de Delaunois [литографировал Делонуа]» художник выступал в роли автора идеи и литографа. Подпись Делонуа по нижнему краю листа - свидетельство авторской работы. Широкие возможности литографии в XIX в. использовали французские художники Т. Жерико, Э. Делакруа, Д. Энгр, А. Гро, О. Домье, П. Гаварни и многие др. Делонуа выступает как увлекательный рассказчик, весело повествует о стремлении добиться расположения возлюбленной, сопровождая пикантную сцену подписью: «Не бойтесь, ваш муж читает «Котидьен». Рокайльная фривольность передается автором нежным акварельным цветом. Прием коллажа гармонично включен в композицию, выражая эмоциональную идею сюжета. 


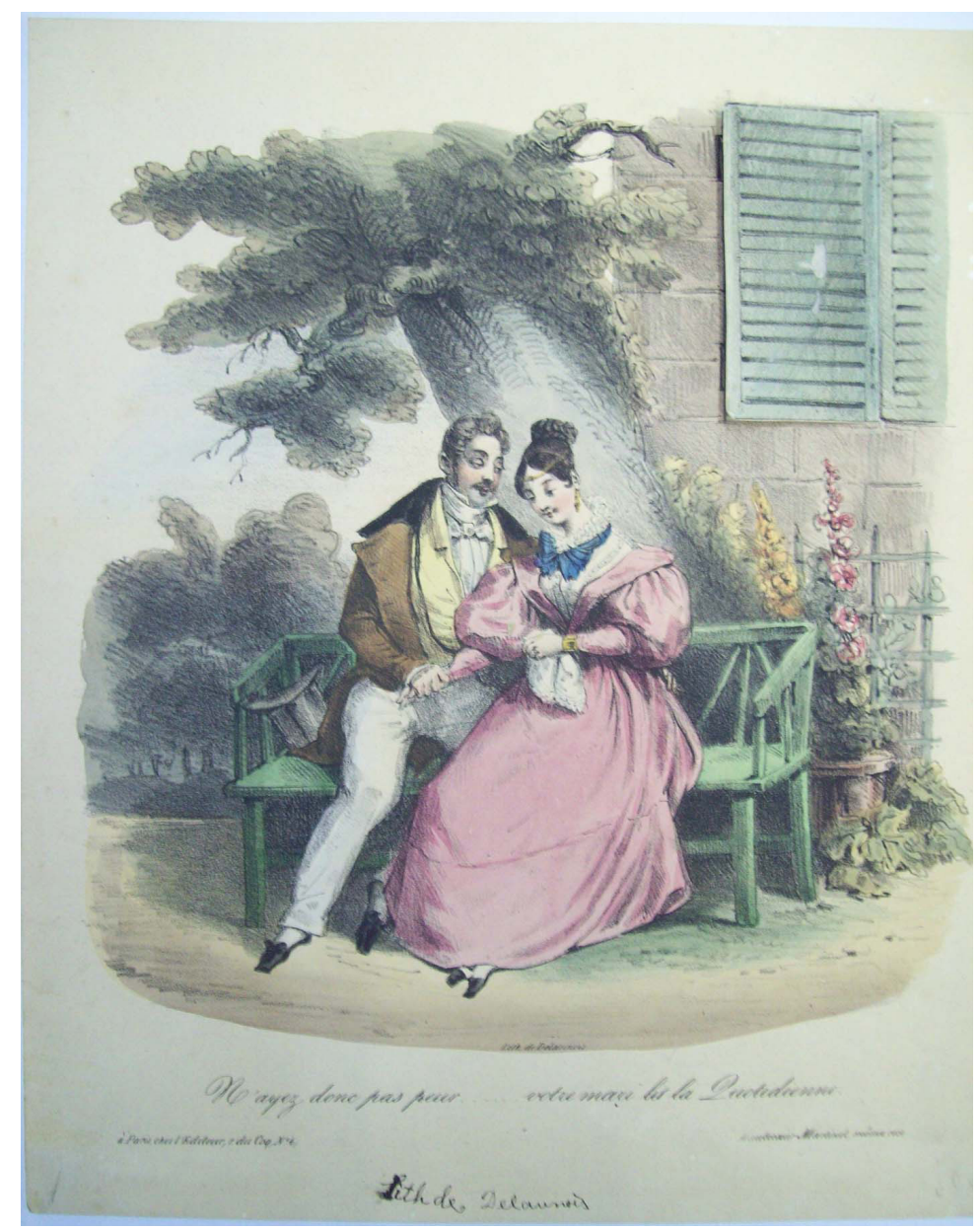

Рис. 7. Делонуа. Не бойтесь, ваш муж читает «Котидьен». XIX в.

Fig. 7. Delaunois. N'ayez donc pas peur... votre mari lit la Quotidienne. $19^{\text {th }}$ century

\section{Заключение}

Подводя итог вышеизложенному, следует отметить, что собрание западноевропейской графики Г.В. Юдина - одна из достопримечательных сибирских коллекций, хранящихся в фондах Красноярского краевого краеведческого музея. Проведенный документальный и искусствоведческий анализ позволил внести уточнения, дополнения и поправки в перевод подписей и текста графических листов коллекции.

Существует давняя проблема подделок и копий. Установить несомненную подлинность гравюры в музейных коллекциях сложно в силу отсутствия имен художника, гравера, так как поля могли быть обрезаны по краю оттиска или изображения. Награвированные подписи не всегда имеют четкий, читаемый шрифт. При указании авторов рисунка, живописного полотна, гравюры, а также гравера, издателя появляются трудности в определении формы участия каждого из них. Довольно часто при переводе возникает проблема адекватной передачи текста, сопровождающего графическое изображение. Обращают на себя внимание имена собственные. К ним можно было применить перевод, осуществленный по принципу фонетического подобия, при котором звучание имени передано звуками принимающего языка. 
Искусствоведческий метод исследования (стилистический, иконографический, исторический, семиотический) в современных условиях, благодаря уникальным возможностям музейного информационного простора, позволил использовать источниковедческие и аналитические ресурсы музейных веб-сайтов. Работа с коллекцией дала возможность внести конкретизацию, выявить выразительные возможности техник гравирования, установить ценность художественных экспонатов - репродукционной, авторской и книжной западноевропейской гравюры. Необходима дальнейшая работа по идентификации собрания европейской гравюры в фондах Красноярского краевого краеведческого музея для включения его в экспозиционное пространство графического искусства.

\section{Список рисунков}

Блау Э.Л. Ночь в Лондоне. Лист 4 из серии «Четыре времени суток». 1833-1834. Автор оригинала У. Хогарт. Литография. 26,7х38,1 см. Альбом репродукций с гравюр У. Хогарта // КККМ в/ф 52. Лист 4. Красноярский краевой краеведческий музей.

Рипенгаузен Э. Л. Автор оригинала:Хогарт, Уильям. Лист 4 Night из серии «Четыре времени суток». Бумага, гравюра резцом. 36х24 см. Государственный Эрмитаж, Санкт-Петербург. URL: http://collections.hermitage.ru/entity/OBJECT/3099450?avtor=5397\&index=5 (дата обращения 05.09.2021).

Бартолоцци Ф. Инветор: Хогарт, Уильям. Продавщица креветок. Бумага, гравюра пунктиром, отпечаток сангиной. 32×25,2 cм. Государственный Эрмитаж, Санкт-Петербург. URL: http://collections.hermitage.ru/entity/OBJECT/907450?avtor=4031\&index=48 (дата обращения 10.09.2021).

Блау Э. Л. Продавщица креветок. Автор оригинала: У. Хогарт. Литография. 32х25,2 см. Альбом репродукций с гравюр У. Хогарта // КККМ в/ф 52. Лист 55. Красноярский краевой краеведческий музей.

Уоллис Р. Кент, Ост-Индская компания. Автор оригинала Дж. Оуэн. 1828. Резцовая гравюра, офорт. // КККМ в/ф 77/2. Красноярский краевой краеведческий музей.

Годар А. Юные садовники. Лист 6 из серии «Детские забавы». Автор оригинала Л. Лассаль. Середина XIX в. Цветная литография. 40,3×26, 5; 22,4x17 см. // КККМ в/ф 5. Лист 6. Красноярский краевой краеведческий музей.

Делонуа. Не бойтесь, ваш муж читает «Кодитьен». XIX в. Цветная литография. 27,2х22,8 см. // // КККМ о/ф 10100/143. Г 1051. Красноярский краевой краеведческий музей.

\section{Список литературы / References}

Britanskaia graviura XVII-XIX vv. iz sobraniia Gjsudarstvennogo Muzeia Izobrazitel'nykh Iskusstv imeni A.S. Pushkina. Chetyre vremeni sutok. Noch' [British Engraving of the $17^{\text {th }}-19^{\text {th }}$ centuries from the collection at State Museum of Visual Arts. The Four Times of the Day. Night in London]. Available at: http://www.britishprints.ru/printmakers/h/hogarth_william/night.html (accessed 11 September 2021).

German, M. Iu. (1977). William Hogart i ego vremia [William Hogarth and his time]. Leningrad, Leningradskoe otdelenie «Iskusstvo», $225 \mathrm{p}$.

Grandville, Jean Ignace Isidore Gérard (2010). Available at: http://dic.academic.ru/dic.nsf/ruwiki/364503 (accessed 27 August 2021).

Iakovleva, S.A. (2019). Russian-English cultural relations in Siberian region in the $18^{\text {th }}$ - early $20^{\text {th }}$ centuries: by example of G. V. Yudin's collection of English literature, graphics and book illustrations [Russkoangliiskie kul'turnye sviazi v Sibirskom regione XVIII - nachala XX v.: na primere sobraniia angliiskoi literatury, grafiki i knizhnoi illiustratsii v kollektsii G. V. Iudina]. Materialy II Mezhdunarodnoi Nauchnoi Konferentsii «Khudozhestvennye traditsii Sibiri» [Proc. $2^{\text {nd }}$ Int. Sc. Conference «Art Traditions of Siberia»]. Krasnoyarsk, 11-15. 
Les Musées de la Ville Paris (2019). Available at: https://www.parismuseescollections.paris.fr/fr/ maison-de-balzac/oeuvres/the-devil-you-always-go-backwards-que-diable-monsieur-on-ne-recule-pas (accessed 20 July 2021).

Mitasova, S., Kostyuk, V., Romanova, E., Shutova, N., Yakovleva, S. (2019). Interaction of Russian, British and American Cultures in Siberia (Case of Literary Preferences), In Advances in Social Science, Education and Humanities Research, 298, available at: https://www.atlantis-press.com/proceedings/ essd-19/125913039 (accessed 20 August 2021).

Polovnikova, I.A. (2010). Gennadii Vasilievich Iudin. Zhizn'. Biblioteka [Gennady Vasilievich Yudin. Life. Library]. Moscow, Tipografia «Novosti», $450 \mathrm{p}$.

Polovnikova, I. (2008). Istoriia prodazhi biblioteki G. V. Iudina [The History of sale of G. V. Yudin's library]. Available at: https://www.krasplace.ru/istoriya-prodazhi-biblioteki-g-v-yudina (accessed 28 July 2021).

Rousseau, J.-J. (1761). Iuliia, or the New Eloisa [Julie, ou la Nouvelle Héloïse]. Available at: https://librebook.me/iuliia_ili_novaia_eloiza/vol3/2 (accessed 15 September 2021).

Struina, E.K., Besedina, N.V., Lobacheva, O.V. (2017). Kollektsiia frantsuzskikh izdanii XIX-nachala $X X v v$. [Collection of French Editions in the $19^{\text {th }}$ - early $20^{\text {th }}$ centuries]. Cheliabinsk, Iuzhno-Ural'skii Gosudarstvennyi Nauchnyi Universitet, $241 \mathrm{p}$.

State Archives of the Krasnoyarsk Territory. Fund 796. Inventory 1. Document 4791a. Sheets 60-61.

State Archives of the Krasnoyarsk Territory. Fund 796. Inventory 1. Unit if issue 4716, 19.

Vodo, N.N. (1987). Frantsuzskaia graviura 18 veka. Ocherki po istorii i tekhnike graviury. Tetrad' 9 [French engraving of the $18^{\text {th }}$ century. Essays on the engraving history and technique. Notebook 9]. Moscow, Izobrazitel'noe iskusstvo, $688 \mathrm{p}$. 